\title{
Agraphorura calvoi n. sp. from Venezuelan caves (Collembola: Onychiuridae)
}

\author{
Javier I. Arbea ${ }^{1}$
}

\begin{abstract}
:
Arbea, J, I. 2005. AGRAPHORURA CALVOI n. sp. from Venezuelan caves (Collembola: Onychiuridae) International Journal of Speleology, 34 (1-2), 19-24. Bologna (Italy). ISSN 0392-6672.

A new species of Agraphorura (Collembola: Poduromorpha: Onychiuridae) from caves in the Nort-West of Venezuela is described. A. calvoi $\mathrm{n}$. sp. can be distinguished from its congeners by the following combination of characters: antennal organ III with four papillae, 32/133/33343 dorsal pseudocellar formula, 3/000/0112 ventral pseudocellar, subcoxae each with two pseudocelli, postantennal organ with 7-9 vesicles, unguiculus with a basal lamella, tibiotarsi I-III with 19,19,18 setae (distal whorl of 9 setae). A table with the differential characters, as well as an identification key for all of the known species of Agraphorura are provided.
\end{abstract}

Keywords: Collembola, Onychiuridae, new species, cave fauna, Venezuela.

Received 6 April 2005; Revised 10 May 2005; Accepted 27 May 2005.

\section{INTRODUCTION}

A new species of Agraphorura Pomorski, 1998 was discovered in two North-West Venezuelan caves. Collembolan investigations at this site were part of the study of cave fauna community patterns from Mesa Turik, Sierra de Perijá, Venezuela (Viloria, Herrera \& Galán, 1992).

The genus Agraphorura was stablished by Pomorski (1988) for Onychiurinae without anal spines, composed granulated vesicles in postantennal organ, furcula reduced to small area of fine granulation, with $2+2$ posterior setulae, and distinct sensilla on body and antenna. He mentioned as particularity for Agraphorura the presence of 7 setae in distal verticil of tibiotarsi, but some species have 9 distal setae on tibiotarsi (see Table I).

Two types of tibiotarsal chaetotaxy are observed: A type: distal whorld of 9 setae (Figs. $14 \& 15$ ). B type: distal whorld of 7 setae (Figs. $12 \& 13$ ).

The number of known species of Agraphorura is eleven, most of them were described originally under the genus Onychiurus Gervais, 1841 (Ellis, 1976; Gama, 1964; Gisin, 1960; Murphy, 1965; Oliveira \& Thibaud, 1992; Palacios-Vargas \& Deharveng, 1982;

1- Departamento de Biología y Geología,

IES Alhama, Avda. del Villar, 44, 31591 Corella (España).

e-mail: jarbeapo@pnte.cfnavarra.es

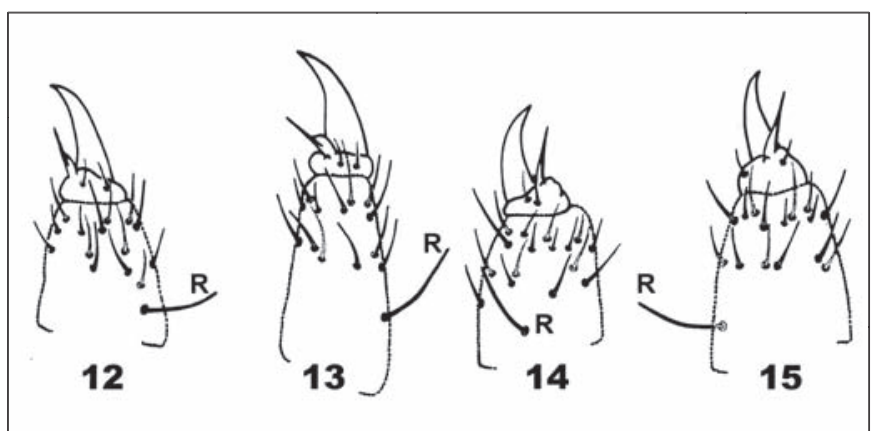

Figs. 12-15. Tibiotarsal chaetotaxy of leg I \& leg III. $12 \& 13$.

Agraphorura acuitlapanensis (paratype female). 14 \& 15. Agraphorura pseudojusti (type female).

Rusek, 1976; Thibaud, 1993; Thibaud \& Massoud, 1979). While the genus is fairly widespread all of the species appear to be very localized and rare. There are three Palaearctic species (A. naglitschi, A. portucalensis and $A$. xenonis), one Etiopic species (A. gambiaria), two nearctic species (A. eisi and $A$. spelaea) and five Neotropical species (A. pseudojusti, A. acuitlapanensis, A. fernandae, A. mariapetrae and A. calvoi n. sp.) .

\section{MATERIALS AND METHODS}

The specimens were taken from two caves located in the Mesa Turik karst, Sierra de Perijá, Zulia State (Venezuela) (Alangua \& Goikoetxea, 1992). Both caves are located at high elevation, about $1500 \mathrm{~m}$ above sea level (Fig. 17 \& 20). Cave systems has been developed on limestone of the Cogollo Group (Cretaceous). 
Cueva de la Pared del Norte or Tashkapa (ZU.52). UTM co-ordinates N 1.152.105; E 751.731; 1750 m above sea level, lateral slope. Cave length $1490 \mathrm{~m}$ (Figs. 18 \& 21). Loose stones floor and large amounts of oilbird guano (Steatornis caripensis Humboldt, 1817, "guácharo"). Our specimens were collected in several parts of the cave, in oilbird guano.
Cueva de los Guácharos (ZU.50). UTM co-ordinates N 1.151.660; E 751.250; $1755 \mathrm{~m}$ above sea level.

Cave lenght $300 \mathrm{~m}$ (Fig. 19). All the places show large amounts of oilbird guano.

Collembola have been extracted by Berlèse method, and preserved in 70 percent ethanol.

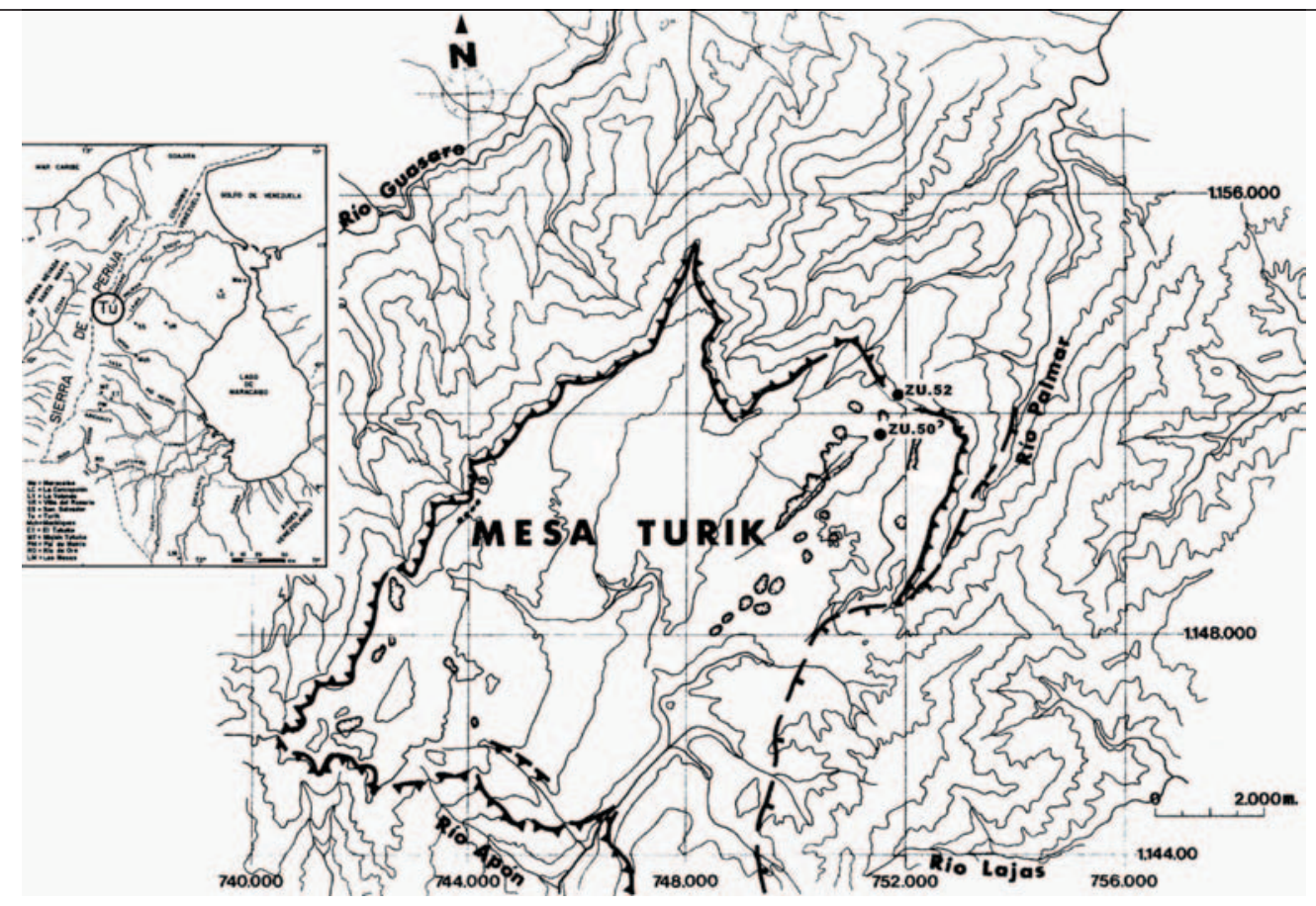

Fig. 17. Location map for the "Mesa Turik" and the cavities (after Alangua \& Goikoetxea, 1992).
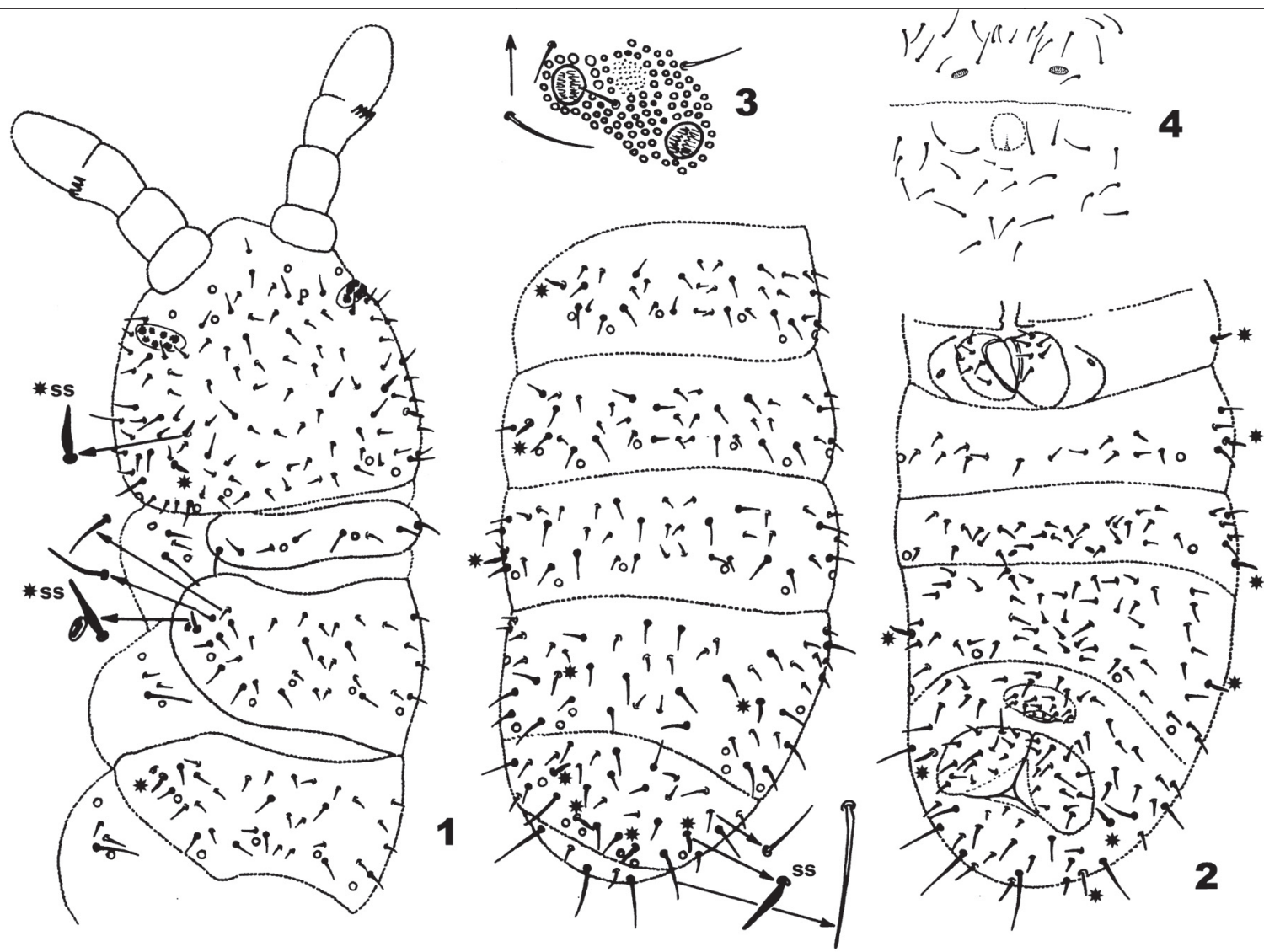

Figs. 1-4. Agraphorura calvoi n. sp. 1. Dorsal chaetotaxy. 2. Ventral abdominal chaetotaxy. 3. Pseudocelli of posterior edge of head. 4. Furcula vestige. 

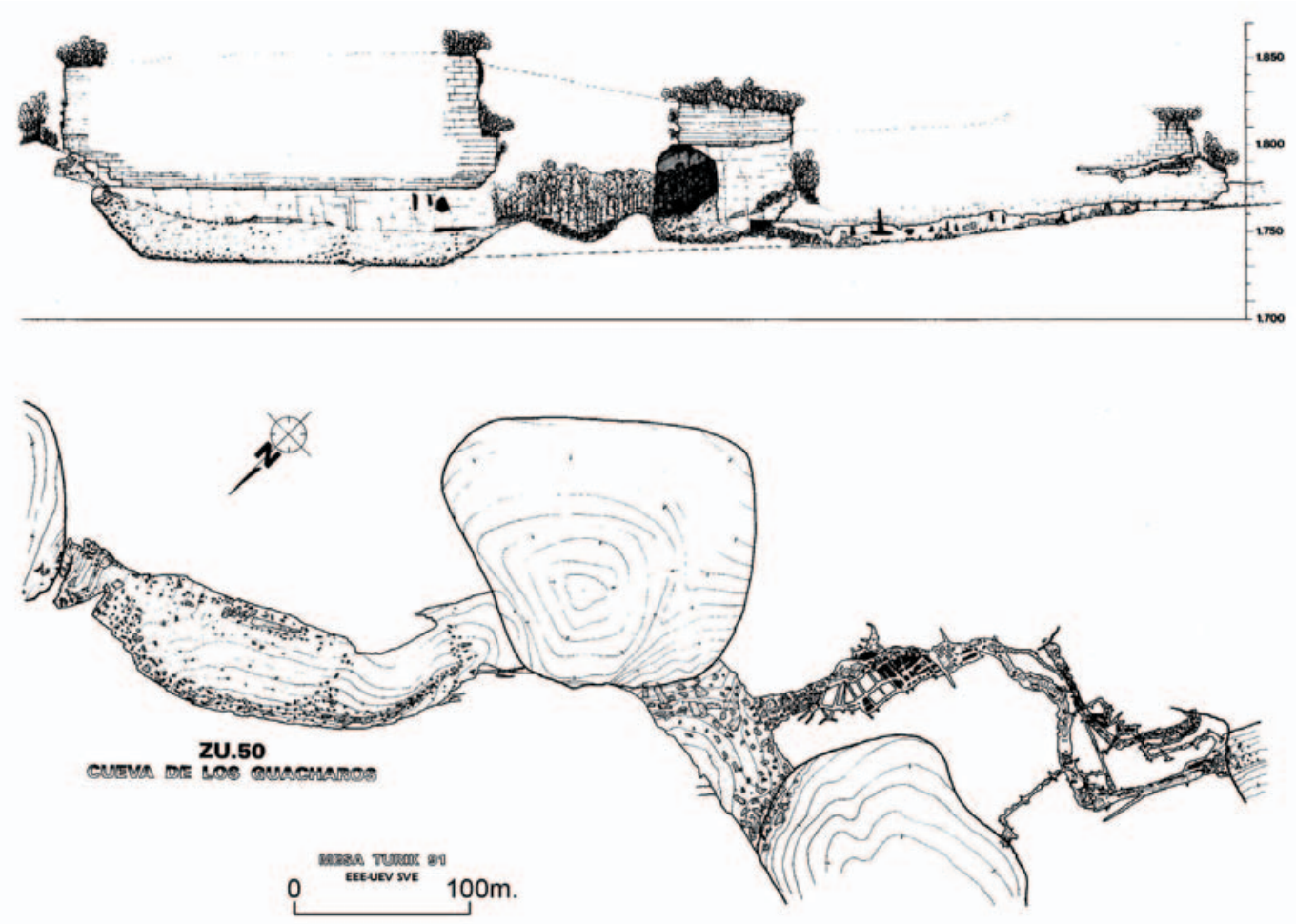

Fig. 19. Topography for the "Cueva de los Guácharos" (ZU.50) (after Alangua \& Goikoetxea, 1992).

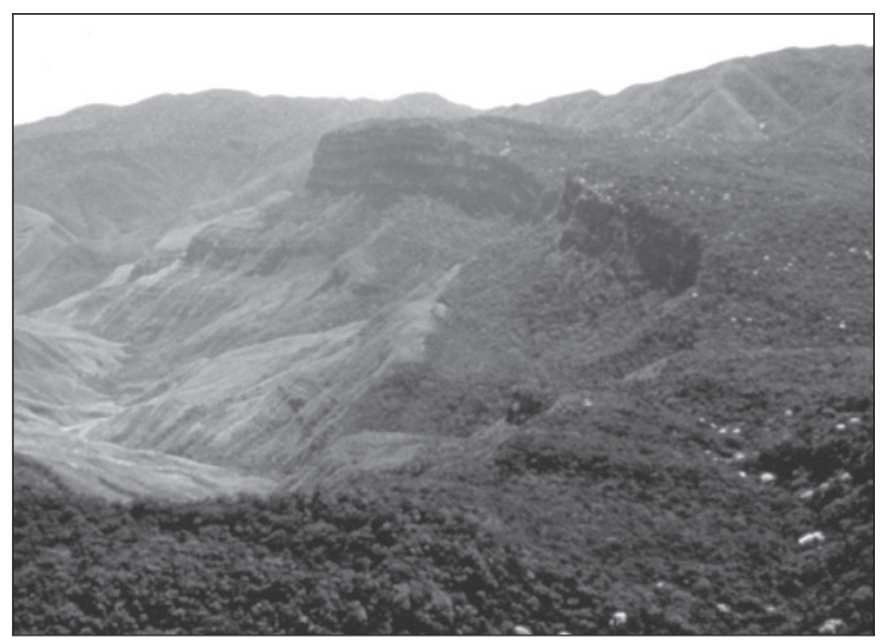

Fig. 20. Mesa Turik karst, Sierra de Perijá, Zulia State (Venezuela) habitat of $A$. calvoi n. sp. (Photo by J.M. Ipiña, UEV-EEE).

Some specimens were mounted on slides using "Hoyer medium".

Abreviations of terms

abd.: abdominal segment.

ant.: antennal segment.

thor.: thoracic segment.

\section{Agraphorura calvoi new species}

(Figs. 1-11 \& 16)

\section{Type material:}

Holotype: male (mounted on slide), Venezuela, Zulia State, Sierra de Perijá, Mesa Turik, Cueva de la Pared del Norte, lateral slope, oilbird guano, 11 March 1991, leg. J.I. Calvo (deposited in the collection of the Laboratorio de Ecología y Sistemática de

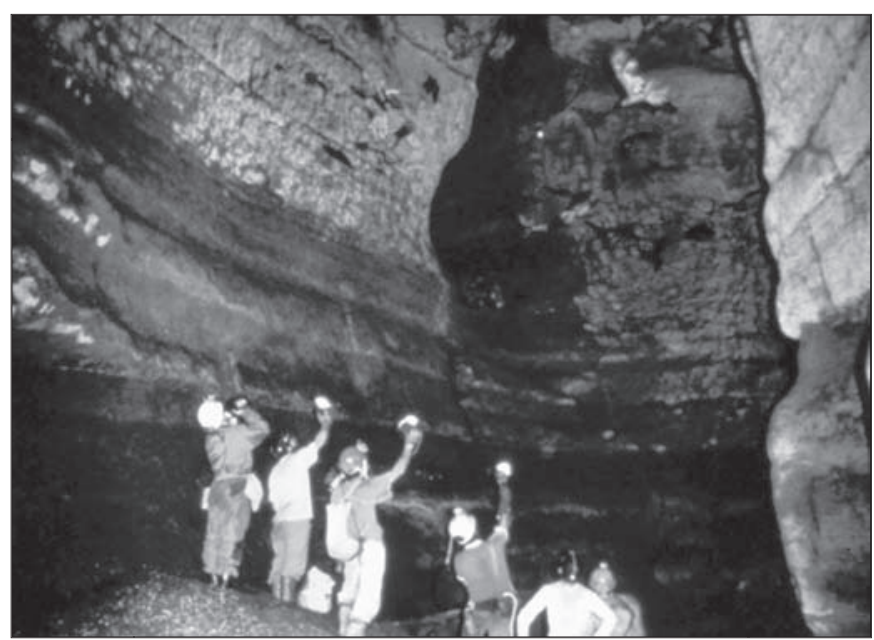

Fig. 21. "Cueva de la Pared del Norte" or Tashkapa - locus typicus of A. calvoi n. sp. (Photo by Peio Zabaleta, UEV-EEE).

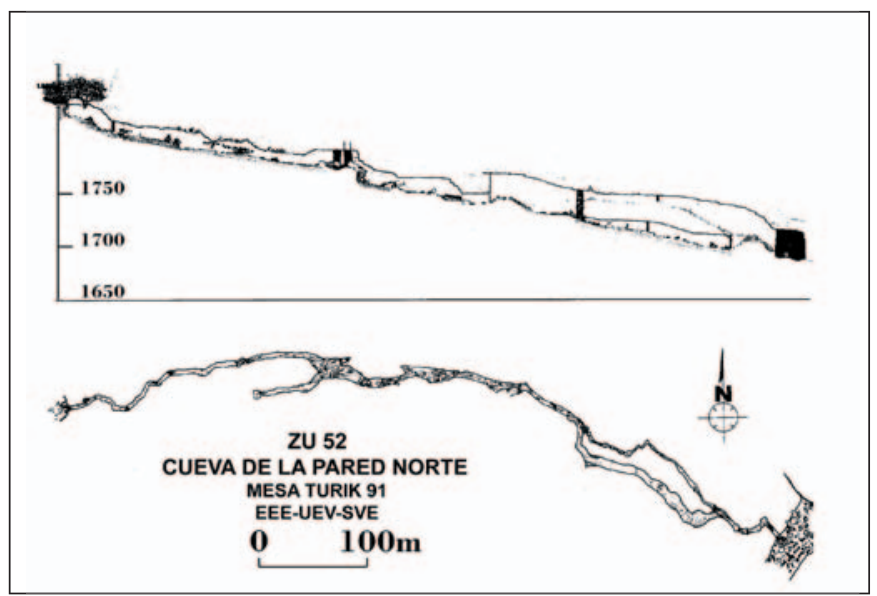

Fig. 18. Topography for the "Cueva de la Pared del Norte" or Tashkapa (ZU.52) (after Alangua \& Goikoetxea, 1992). 
Microartrópodos, UNAM, Mexico).

Paratypes: same data as for holotype, 3 males and 10 females on slides (deposited in author's collection), 120 specimens in ethyl alcohol (deposited in the collection of the Laboratorio de Ecologia y Sistemática de Microartrópodos, UNAM, Mexico).

Other material studied. Same locality as for holotype, 13 March 1991, 61 specimens on slides and in ethyl alcohol. Venezuela, Zulia State, Sierra de Perijá, Mesa Turik, Cueva de los Guácharos, oilbird guano, 15 March 1991, 3 specimens on slide (deposited in author's collection).

\section{Diagnosis:}

Postantennal organ, composed of 7-9 granulated vesicles. Furcula reduced to small area of fine granulation with $2+2$ setulae arranged in two rows. Pseudocellar formula dorsally: 32/133/33343; ventrally: 3/000/0112 pseudocelli and 0/000/101 parapseudocelli; on subcoxa two pseudocelli. Tibiotarsi with symmetrical distal verticil, composed of 9 setae. Dorsal chaetotaxy of head with seta $d_{0}$.

\section{Description:}

Color white. Length: males - 0.65-0.75 mm, females - 0.70-0.85 mm. Body shape cylindrical (Figs. 1 and 2), with small VI abdominal segment, dorsally accreted with abdominal tergum V. Body granulation generally uniform and fine (Fig. 3), antennal bases no well delimited.

Antennae. Nearly as long as head. Ratio antennae: head diameter as $10: 11-13$. Ant. I and II with 8 and 14 acuminate setae, respectively. Ant. III with 19 acuminate setae and two blunt-tipped setae. Antennal organ III with 4 guard setae, 4 digital papillae, covering 2 large, bent and distinctly swollen sensory clubs. 2 sensory rods small, slightly bent, hidden under sensory clubs (Fig. 5). Microsensillum inserted slightly below antennal organ III. Antennal segment IV short and spherical; with some 24 blunt dorsal setae; a subapical organite; a dorso-external microsensillum, distinctly above posterior setae; and a thick, internal sensillum. Ratio Ant. I:II;III;IV are as 10:15;15;20 (Fig. 5).

Head. Postantennal organ relatively short with 7-9 composed granulated vesicles (Fig. 8). Labrum with 9 setae $(3,4,2), 4$ prelabral setae. Labium AB type.

Pseudocellar formulae. Dorsal 32/133/33343 pseudocelli, lateral pseudocelli on abdominal tergites IV and $\mathrm{V}$ are located in very lateral position, and may be difficult to see; ventral 3/000/0112 pseudocelli and 0/000/101 parapseudocelli (Figs. 2 and 9); subcoxae each with 2 pseudocelli.

Body chaetotaxy. Thoracic terga II and III with large lateral microsensilla. Dorsal chaetotaxy nearly symmetric, poorly differentiated into meso- and microchaetae (Figs. 1 and 6). Sensilla very well differentiated and visible on body (Fig. 1). Sensilla formula: dorsal 2/011/111121, ventral 2/000/0001, subcoxa $0 / 0 / 1$. Lateral microsensilla present on thor. II and III. Head with seta $d_{0}$. Thoracic tergum I with 4+4 setae, abdominal terga IV and V without medial setae, abd. VI with one medial seta. No setae between legs on thorax I-III. Ventral tube without basal setae and $6+6$ setae on the shaft. Male ventral organ absent. Anal spines absent. Abd. VI with 11+11 anal setae and 3 microchaetae on each anal lobe (Fig. 7). Males with 4+4 eugenital setae and some 26 circumgenital ones. Females with $2+2$ eugenital setae, 10-12 circumgenital and 4-5+4-5 pregenital setae.

Legs. Subcoxae with 2,4,4 setae. Tibiotarsi I-III with $19,19,18$ setae (distal whorl of 9 setae, $B_{1-7}$ acuminate

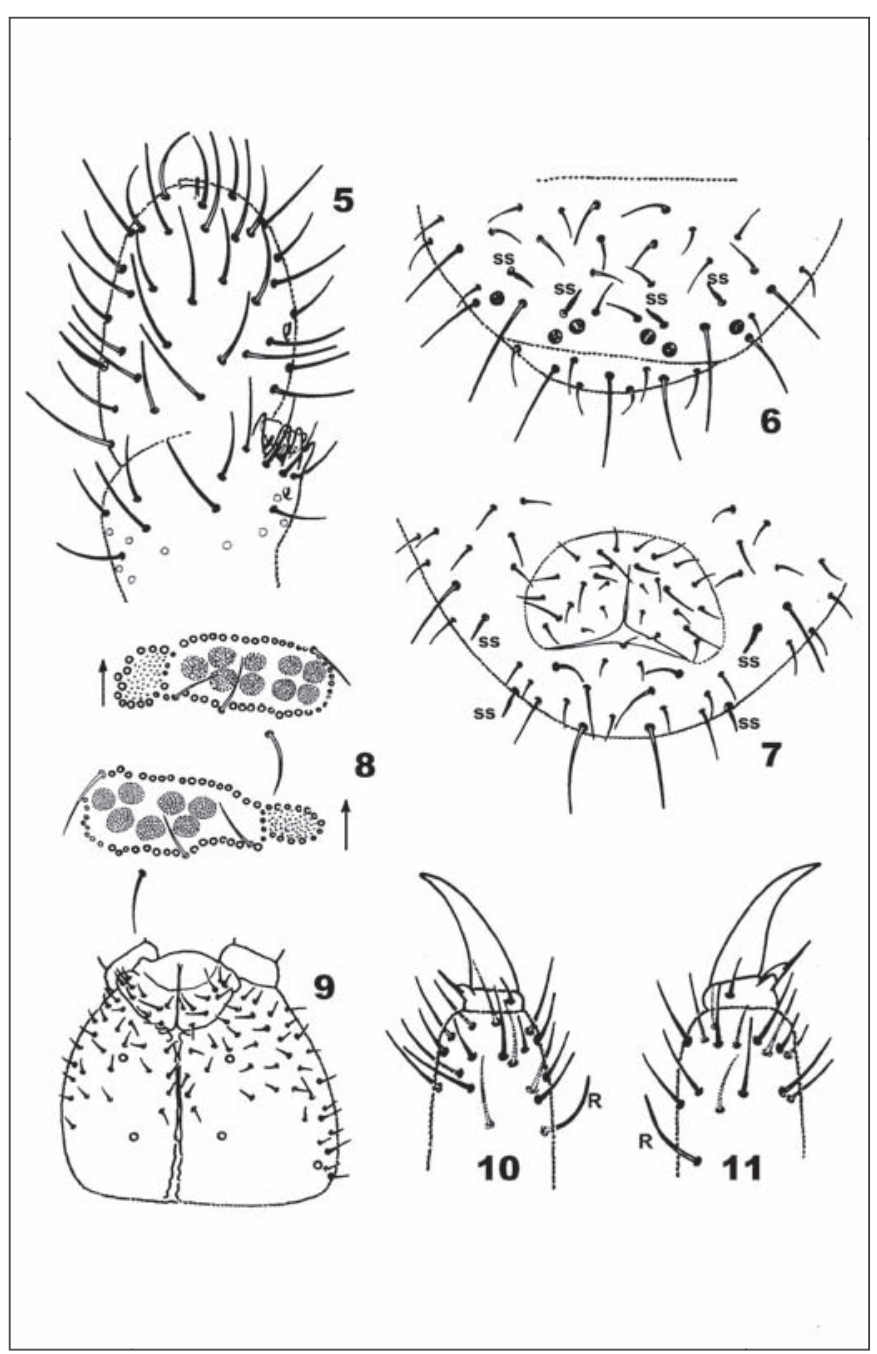

Figs. 5-11. Agraphorura calvoi n. sp. 5. Antennal segments III and IV. 6. Chaetotaxy of abdominal terga V-VI. 7. Chaetotaxy of abdominal sterna V-VI. 8. Postantennal organ. 9. Ventral cephalic chaetotaxy. 10. Tibiotarsal chaetotaxy and claw of leg I. 11. Tibiotarsal chaetotaxy and claw of leg III.

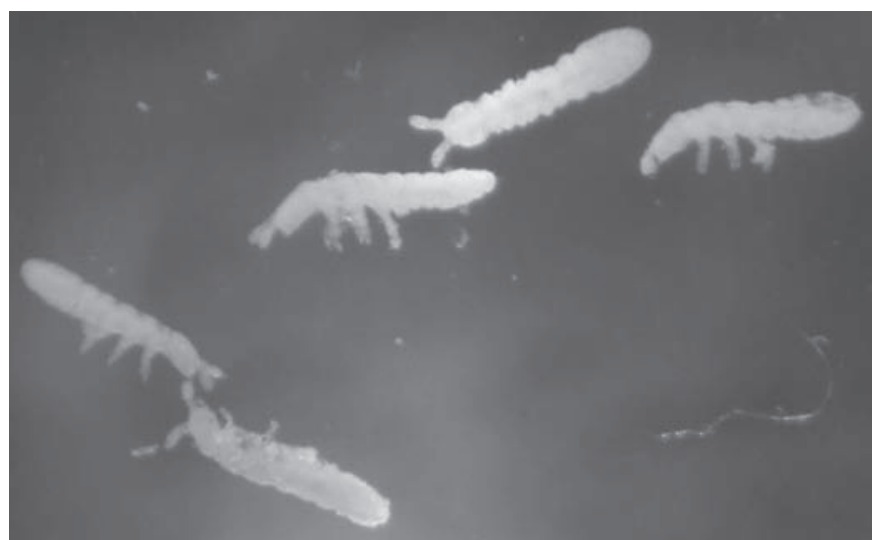

Fig. 16. Agraphorura calvoi n. sp. Habitus. 
setae; Y blunt-tipped seta). Tibiotarsal seta $B_{7}$ absent on tibiotarsus III. Claw narrow, without teeth 2.7-2.8 as long as width at the base. Unguiculus with a small, basal lamella, about $1 / 2$ as long as inner unguis. Ratio tibiotarsus: claw, as 1.6 : 1 (Figs. 10 and 11).

Furcula. Reduced to small area of fine granulation located on abdominal sternum IV near border of abdominal sternum III, with $2+2$ setulae arranged in two rows (Fig. 4).

Etymology: The name is dedicated to José Ignacio Calvo, who kindly provided the material.

\section{DISCUSSION}

The shape of furcal remnant, lack of anal spines, and distinct sensilla on body and antenna show that the new species belongs to the genus Agraphorura. Whithin the genus, the new species is characterized by the ventral pseudocellar formula and the tibiotarsal chaetotaxy.
A. calvoin. sp. is similar to A. acuitlapanensis in the number of papillae on antennal organ III, the dorsal pseudocellar formula, the number of vesicles on postantennal organ and the chaetotaxy of thoracic tergum I. It differs in the number of pseudocelli on subcoxae and the tibiotarsal chaetotaxy (see Table I). Because of the tibiotarsal chaetotaxy type (A type: distal whorld of 9 setae; see Table I) A. calvoi n. sp. resembles the Caribbean species $A$. pseudojusti and A. mariapetrae, from which it differs in the ventral pseudocellar formula and the chaetotaxy of thor. I and II. Besides, A. pseudojusti have two pseudocelli on abd. V (A. mariapetrae and A. calvoi n. sp.: three pseudocelli on abd.V).

\section{ACKNOWLEDGEMENTS}

I wish to thank Mr. José Ignacio Calvo for the collection of material. I am indebted also to the "Grupo Espeleológico Satorrak", the "Unión de

\section{Key to the known species of Agraphorura (adults or subadults)}

The key presented here was compiled based on the work of Pomorski (2004) with the new species added.

1. Antennal organ III with 5 papillae

-. $\quad$ Antennal organ III with 4 papillae

2. Abdominal terga I-III with $4+4$ pseudocelli

-. $\quad$ Abdominal terga I-III with $3+3$ pseudocelli

3. Thoracic tergum I with $2+2$ pseudocelli. Antennal organ III with 5 very long, digital papillae, covering 2 large, bent and distinctly swollen sensory clubs; 2 small sensory rods, softly bent, hidden under sensory clubs

-. $\quad$ Thoracic tergum I with $1+1$ pseudocelli. Antennal organ III with 5 typical papillae, 2 smoth sensory clubs and 2 typical sensory rods

4. Ventral pseudocellar formula 4/000/2222

-. $\quad$ Ventral pseudocellar formula 2/000/1212

5. Thoracic tergum I with $4+4$ setae

-. Thoracic tergum I with $5+5$ setae

6. Postantennal organ with 11 vesicles

-. Postantennal organ with 7-9 vesicles

7. Ventral pseudocellar formula 3/000/0-1112; subcoxae with 1 pseudocellus. Tibiotarsi with distal verticil composed of 7 setae Ventral pseudocellar formula 3/000/0212: subcoxae with 2 pseudocelli. Tibiotarsi with distal verticil composed of 9 setae

8. Abdominal sterna without pseudocelli

-. Abdominal sterna with pseudocelli

9. Ventral pseudocellar formula 3/011/122?

-. Ventral pseudocellar formula 3/000/1212

-. $\quad$ Ventral pseudocellar formula 3/000/2222
2

5

A. portucalensis 3

\section{A. spelaea}

4
A. xenonis
A. naglitschi

6

8

A. gambiaria

A. acuitlapanensis

A. calvoi n. sp.

A. eisi

9

A. pseudojusti

A. mariapetrae

A. fernandae 
Table I. Differential characters for all of the known species of Agraphorura.

\begin{tabular}{|c|c|c|c|c|c|c|c|c|c|c|}
\hline Agraphorura & 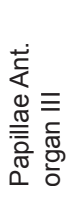 & 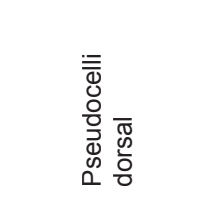 & 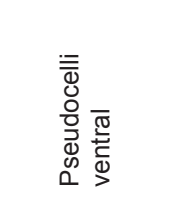 & 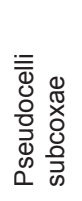 & $\begin{array}{l}0 \\
\frac{1}{0} \\
\frac{0}{0} \\
0 \\
0 \\
0 \\
0 \\
0\end{array}$ & 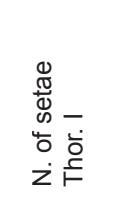 & 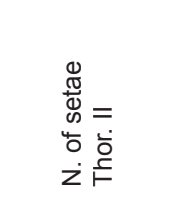 & 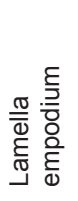 & 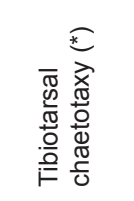 & 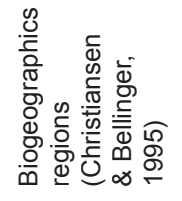 \\
\hline A. naglitschi (Gisin, 1960) & 5 & $32 / 133 / 33353$ & $2 / 000 / 1212$ & $2 / 2 / 2$ & $8-10$ & $6+6$ & $16+16$ & $(+)$ & B type & Europe \\
\hline $\begin{array}{l}\text { A. portucalensis } \\
\text { (Gama, 1964) }\end{array}$ & 5 & $34 / 133 / 44464$ & $4 / 000 / 2212$ & $2 / 2 / 2$ & $12-14$ & $6+6$ & $21+21$ & - & $\begin{array}{l}\text { B type } \\
16 / 16 / 15\end{array}$ & Mediterranean \\
\hline $\begin{array}{l}\text { A. gambiaria } \\
\text { (Murphy, 1965) }\end{array}$ & 4 & 32/---/---- & $3 / 000 / 0212$ & $2 / 2 / 2$ & 11 & $4+4$ & & & & $\begin{array}{l}\text { Sudanese Park } \\
\text { Steppe }\end{array}$ \\
\hline $\begin{array}{l}\text { A. xenonis } \\
\text { (Ellis, 1976) }\end{array}$ & 5 & $32 / 133 / 33354$ & $4 / 000 / 2222$ & & 12 & $6+6$ & & - & B type & Mediterranean \\
\hline $\begin{array}{c}\text { A. eisi } \\
\text { (Rusek, 1976) }\end{array}$ & 4 & $32 / 133 / 33343$ & $1 / 000 / 0000$ & $1 / 1 / 1$ & $5-7$ & $5+5$ & $19+19$ & - & $?$ & $\begin{array}{l}\text { Pacific North } \\
\text { American }\end{array}$ \\
\hline $\begin{array}{c}\text { A. pseudojusti } \\
\text { (Thibaud \& Massoud, 1979) }\end{array}$ & 4 & $32 / 133 / 33342$ & $3 / 111 / 122 ?$ & $1 / 1 / 1$ & $9-11$ & $5-6+5-6$ & $20-21+20-21$ & $(+)$ & $\begin{array}{l}\text { A type } \\
17 / 18 / 16\end{array}$ & $\begin{array}{l}\text { Caribbean } \\
\text { mainland }\end{array}$ \\
\hline $\begin{array}{c}\text { A. acuitlapanensis } \\
\text { (Palacios-Vargas \& } \\
\text { Deharveng, 1982) }\end{array}$ & 4 & $32 / 133 / 33343$ & $3 / 000 / 0-1112$ & $1 / 1 / 1$ & 8 & $4+4$ & $16+16$ & + & $\begin{array}{l}\text { B type } \\
15,15,14\end{array}$ & $\begin{array}{l}\text { Caribbean } \\
\text { mainland }\end{array}$ \\
\hline $\begin{array}{l}\text { A. fernandae } \\
\text { (Oliveira \& Thibaud, 1992) }\end{array}$ & 4 & $32 / 133 / 33343$ & $3 / 000 / 2222$ & $2 / 2 / 2$ & 8-12 & $5+5$ & $20-21+20-21$ & + & $?$ & Amazon \\
\hline $\begin{array}{l}\text { A. mariapetrae } \\
\text { (Thibaud, 1993) }\end{array}$ & 4 & $32 / 133 / 33343$ & $3 / 000 / 1212$ & $2 / 2 / 2$ & $11-13$ & $5+5$ & $20-21+20-21$ & + & $\begin{array}{l}\text { A type } \\
17 / 18 / 16\end{array}$ & $\begin{array}{c}\text { Caribbean } \\
\text { mainland }\end{array}$ \\
\hline $\begin{array}{c}\text { A. spelaea } \\
\text { Pomorski, } 2004\end{array}$ & 5 & $32 / 233 / 3335(4) 3$ & $3 / 011 / 1212$ & $2 / 3 / 3$ & $20-21$ & $4+4$ & $19+19$ & + & B type & $\begin{array}{l}\text { Pacific North } \\
\text { American }\end{array}$ \\
\hline A. calvoi $\mathrm{n}$. sp. & 4 & $32 / 133 / 33343$ & 3/000/0112 & $2 / 2 / 2$ & $7-9$ & $4+4$ & $19+19$ & + & $\begin{array}{c}\text { A type } \\
17,17,16\end{array}$ & $\begin{array}{c}\text { Venezuela \& } \\
\text { Guiana }\end{array}$ \\
\hline
\end{tabular}

$\left({ }^{*}\right)$ Tibiotarsal chaetotaxy. A type (distal whorld of 9 setae: Figs. 14 \& 15), B type (distal whorld of 7 setae: Figs. 12 \& 13 ).

Espeleólogos Vascos, UEV-EEE" and the "Sociedad Venezolana de Espeleología" for funding a project to carry out prospecting work in "Mesa Turik". José Guadalupe Palacios-Vargas (Laboratorio de Ecología y Sistemática de Microartrópodos, UNAM, Mexico) and Jean-Marc Thibaud (Laboratoire d'Entomologie, Muséum national d'Histoire naturelle, Paris) kindly provided specimens of A. acuitlapanensis, A. pseudojusti and A. mariapetrae. Thanks also to Romuals Jacek Pomorski for invaluable comments about the genus Agraphorura.

\section{REFERENCES}

Alangua, F. \& Goikoetxea, I., 1992 - Descripción física de las cavidades exploradas en Mesa Turik. Karaitza, 1: $17-28$.

Christiansen, K.A. \& Bellinger, P.F., 1995 - The biogeography of Collembola. Bulletin Entomologique de Pologne, 64: 279-294.

Ellis, W.N., 1976 - Autumn fauna of Collembola from central Crete. Tjdschrift voor Entomologie, 119: 221-326.

Gama, M.M., 1964 - Colêmbolos de Portugal Continental. Memórias e Estudos do Museu Zoológico da Universidade da Coimbra, 292: 1-252.

Gisin, H., 1960. Sur la faune européenne des Collemboles III. Revue Suisse de Zoologie, 67: 309-322.
Murphy, D.H., 1965 - Collembola Poduromorpha from the Gambia (West Africa). Journal of Zoology, 146: 388-411.

Oliveira, E. \& Thibaud, J.-M., 1992 - Notes sur les collemboles de l'Amazonie, Brésil. 1. Hypogastruridae et Onychiuridae, avec la description de deux espèces nouvelles (Collemboles). Opuscula Zoologica Fluminenesia, 95: 1-8.

Palacios-Vargas, J.G. \& Deharveng, L., 1982 - Onychiurus acuitlapanensis n. sp. (Collembola: Onychiuridae) cavernícola de México. Nouvelle Revue d'Entomologie, 12(1): 3-7.

Pomorski, R.J., 1998 - Onychiurinae of Poland (Collembola: Onychiuridae). Genus, supplement: 1-201.

Pomorski, R.J., 2004 - Agraphorura spelaea n. sp. (Collembola: Onychiuridae) from North American caves. Journal of Cave and Karst Studies, 66(3): 76-80.

Rusek, J., 1976 - New Onychiuridae (Collembola) from Vancouver Island. Canadian Journal of Zoology, 54: 19-41.

Thibaud, J.-M., 1993 - Les Collemboles des Petites Antilles. VI. Interstitiels terrestres et marins. Revue française d'Entomologie (N.S.), 15(2): 69-80.

Thibaud, J.-M. \& Massoud, Z., 1979 - Les Collemboles des Petites Antilles. I.- Hypogastruridae et Onychiuridae. Revue d'Écologie et de Biologie du Sol, 16(4): 547-567.

Viloria, A., Herrera, F. \& Galán, C., 1992 - Resultados preliminares del estudio del material biológico colectado en Turik. Karaitza, 1: 29-30. 